\title{
PERANAN MUSYAWARAH MUFAKAT (BUBALAH) DALAM MEMBENTUK IKLIM AKADEMIK POSITIF DI PRODI PPKN FKIP UNILA
}

\author{
Yesi Eka Pratiwi ${ }^{1}$ dan Sunarso ${ }^{2}$ \\ ${ }^{1}$ Mahasiswa Prodi PPKn, Program Pascasarjana, Universitas Negeri Yogyakarta \\ ${ }^{2}$ Dosen Prodi PPKn, Program Pascasarjana, Universitas Negeri Yogyakarta \\ Email:yesiekapratiwi2@gmail.com
}

\begin{abstract}
ABSTRAK, Penelitian ini bertujuan adalah untuk mendeskripsikan peranan budaya musyawarah mufakat (Bubalah) dalam membentuk iklim akademik positif pada civitas akademika di Program Studi PPkn FKIP Universitas Lampung. Penelitian ini menggunakan pendekatan kualitatif dengan jenis studi kasus. (Bubalah) merupakan salah satu tradisi adat Lampung yang diadopsi oleh Program Studi PPkn FKIP Universitas Lampung sebagai budaya akademik. (Bubalah) atau musyawarah mufakat memiliki makna yang sama yakni berkumpul bersama untuk menyelesaikan persoalan melalui musyawarah. Dalam pelaksanaannya, budaya musyawarah mufakat (Bubalah) di agendakan tiga kali dalam satu semester, yaitu di awal, di tengah, dan di akhir semester. Budaya musyawarah mufakat (Bubalah) memiliki peranan sebagai jembatan untuk mempersatukan civitas akademika di program studi PPKn FKIP Universitas Lampung menjadi satu kesatuan yang utuh dalam membentuk iklim akademik yang positif, melalui hubungan kekeluargaan yang harmonis diantara civitas akademika. Selain itu budaya musyawarah mufakat (Bubalah) juga berfungsi sebagai wadah dalam menampung aspirasi seluruh civitas akademika agar dapat tersalurkan dengan baik. Pengembangan budaya musyawarah mufakat (Bubalah) merupakan sebuah langkah yang diambil Ketua Program Studi PPkn FKIP Universitas Lampung untuk mempertahankan kebudayaan lokal agar tetap terjaga kelestariannya. Proses pengambilan keputusan dalam musyawarah mufakat (Bubalah) merupakan konsensus bangsa Indonesia dan dinilai sebagai cara yang lebih efisien dalam mencapai keputusan bersama (win-win solution). Pada praktik nyata di lapangan menunjukan bahwa mahasiswa mulai enggan untuk melestarikan budaya musyawarah mufakat (Bubalah) karena dalam pelaksanaannya memakan waktu yang relatif lama, sehingga mahasiswa lebih memilih sistem voting yang lebih praktis di bandingkan musyawarah mufakat (Bubalah).
\end{abstract}

Kata kunci: bubalah; budaya musyawarah mufakat; iklim akademik

\section{THE ROLE OF DISCUSSION CONSENSUS (BUBALAH) IN SHAPING POSITIVE ACADEMIC CLIMATE PPKN COURSE FKIP UNILA}

\begin{abstract}
The study aims to describe the role of deliberation cultural in shaping positive academic climate in the academic community in Civic Education Program University of Lampung. And uses a qualitative approach with a type of case study. (Bubalah) is one of the Lampung traditions adopted by the Civic Education Program University of Lampung as academic culture. (Bubalah) has the same meaning that is gathered together to solve the problem through deliberation. In its implementation, the culture of consensus deliberation (Bubalah) is done three times in one semester, at the beginning, in the middle, and at the end of semester. Bubalah has a role as a bridge for unifier in the Civic Education Program of the University of Lampung in shaping a positive academic climate, harmonious kinship between the academic community. Besides Bubalah culture has a function as a container in accommodating the aspirations of the entire academic community well. The development of a consensus deliberation culture (Bubalah) is a step taken by the Head of Citizenship Education Program University of Lampung to maintain local culture in order to maintain its sustainability. The decision-making process through deliberation is the agreement of the Indonesian people and is considered a more efficient way to reach joint decisions. In real practice on the ground shows that students are starting to not conserve consensus culture (Bubalah) because the implementation takes a relatively long time, so that students prefer to do a more practical voting than consensus deliberation (Bubalah).
\end{abstract}

Key words: bubalah; cultural consensus discussion; the academic climate

\section{PENDAHULUAN}

Indonesia merupakan salah satu negara kepulauan yang memiliki beranekaragam budaya, suku, ras, dan bahasa daerah. Sebagai negara kepulauan dengan memiliki wilayah yang luas dari Sabang sampai Merouke dan berjajar pulau-pulau yang terbentang luas, setidaknya terdapat 17.504 pulau yang tersebar di seluruh penjuru Indonesia, yang terdiri atas 8.651 pulau yang bernama dan 8.853 pulau yang belum bernama. Di samping berlimpah ruahnya kekayaan alam yang dimiliki oleh bangsa Indonesia, juga terdapat beragam budaya yang tumbuh dan berkembang di dalamnya, budaya itu sendiri yang nantinya akan mewarnai bangsa ini. Hampir di setiap daerah memiliki budaya tersendiri yang mewakili daerahnya untuk menjadi ciri khas dari daerah tersebut. Budaya merupakan salah satu identitas dari suatu bangsa yang tercermin melalui pelestarian budaya tersebut dalam kehidupan sehari-hari. Pelestarian budaya itu sendiri merupakan salah satu kegiatan untuk menjaga dan mempertahankan agar keasrian budaya tersebut tidak hilang, kegiatan pelestarian dapat digunakan juga sebagai wahana educatif dalam mempertahankan local wisdom setempat.

Budaya yang hakikatnya merupakan suatu sarana pendidikan dalam membentuk pola pikir, sikap dan kepribadian putra-putri bangsa sesuai dengan normanorma yang berlaku. Kausar (2013: 27) mengartikan 
bahwa budaya merupakan salah satu konsep dalam antropologi yang dapat pula diterapkan dalam sebuah organisasi. Budaya juga memiliki beberapa nilai-nilai yang perlu diperhatikan keberadaannya, Hindaryatiningsih (2016: 108-109) menjelaskan bahwa nilai budaya sangat penting karena dapat digunakan sebagai sebagai seperangkat keyakinan yang mempengaruhi sikap dan perilaku seseorang atau kelompok dalam kehidupanya di masyarakat.

Untuk memahami budaya, bukan hanya sekedar mengerti, akan tetapi harus benar-benar paham arti dan makna daribudayaitu sendiri. Salah satukarakterpenting dari budaya adalah budaya itu perlu dipelajari dari lahir hingga akhir hidup. Budaya musyawarah mufakat merupakan kegiatan berembuk dan berunding untuk memecahkan masalah yang manghasilkan kesepakatan bersama (winwin solution). Musyawarah mufakat bertujuan untuk mempererat tali kekeluargaa seperti halnya yang tertera pada Sila ke empat Pancasila "Kerakyatan Yang Dipimpin Oleh Hikmat Kebijaksanaan dalam Permusyawaratan / Perwakilan”. Musyawarah mufakat merupakan proses membahas persoalan secara bersama demi mencapai kesepakatan bersama. Musyawarah mufakat dilakukan sebagai cara untuk menghindari pemungutan suara yang menghasilkan kelompok minoritas dan mayoritas.

Pada kenyataannya musyawarah mufakat justru digantikan dengan sistem voting, yang hakikatnya berlawanan arah dengan musyawarah mufakat. Voting dilakukan dengan pemungutan suara di mana suara terbanyak akan menjadi penentunya, sedangkan hakikat musyawarah mufakat merupakan kegiatan berunding dan berembuk untuk mencari jalan keluar bersama tanpa merugikan salah satu pihak dan keputusan tersebut berasal dari kesepakatan bersama. Akan tetapi tidak banyak mahasiswa yang berminat melestarikan musyawarah mufakat dengan dalih kesibukan yang makin padat, sehingga enggan untuk meluangkan waktunya dan memilih cara yang lebih praktis yakni voting. Dalam kehidupan sehari-hari musyawarah mufakat dibudayakan untuk menciptakan kerukunan, keharmonisan, toleransi, dan kekeluargaan. Namun pandangan lain tentang musyawarah mufakat juga tidak dapat ditepis bahwa tidak semua mahasiswa memiliki waktu luang dan kesibukan yang sama, untuk ikut dalam kegiatan musyawarah mufakat.

Musyawarah mufakat dalam bingkai tradisi adat Lampung dikenal dengan sebutan (Bubalah)yang artinya musyawarah. Bentuk lain budaya musyawarah mufakat yang mulai hilang termakan oleh kebutuhan birokrasi saat ini yakni dari musyawarah menjadi voting. Musyawarah mufakat dalam budaya Lampung disebut dengan (Bubalah). Tradisi (Bubalah) sendiri terus dilestarikan dalam berbagai sendi kehidupan masyarakatnya. Seperti yang akan dipaparkan dalam penelitian ini yakni peranan budaya musyawarah mufakat (Bubalah) dalam membentuk iklim akademik positif di Program Studi
PPkn FKIP Universitas Lampung. Program Studi PPkn FKIP Universitas Lampung mengadopsi tradisi (Bubalah) menjadi budaya akademik di Program Studi PPkn FKIP Universitas Lampung. Pengadopsian (Bubalah) tersebut dilakukan untuk melestarikan salah satu tradisi adat Lampung yang saat ini mulai tergerus oleh arus globalisasi, ditambah dengan jumlah transmigrasi dari berbagai daerah yang mengakibatkan melunturnya tradisi adat Lampung. Tujuan Program Studi PPkn FKIP Universitas Lampung mengadopsi tradisi (Bubalah) adalah membiasakan kepada mahasiswa untuk membudayakan musyawarah mufakat dalam setiap pengambilan keputus-an, sebagai sarana pengimplementasian salah satu nilai Pancasila, sebagai wadah untuk mengasah sikap demokratis mahasiswa, dan untuk menciptakan iklim yang positif dan damai. Bentuk lain (Bubalah) yang diterapkan oleh Program Studi PPkn FKIP Universitas Lampung ialah MUBES (Musyawarah Besar) yang diprakarsai oleh FORDIKA (Forum Pendidikan Kewarganegaraan).

Salah satu usaha yang dilakukan oleh Program Studi PPkn FKIP Universitas Lampung untuk menciptakan iklim akademik yang positif, kondusif, dan harmonis ialah dengan menerapkan budaya musyawarah mufakat (Bubalah). Fattah Bahiki \& Rahmatan (1993: 2) menyatakan bahwa Bubalah artinya musyawarah. Budaya musyawarah mufakat (Bubalah) yang diselenggarakan oleh Program Studi PPkn FKIP Universitas Lampung, memiliki peranan terhadap pembentukan iklim akademik yang positif. Budaya musyawarah mufakat (Bubalah) memberikan rangsangan terhadap lingkungan di sekitarnya untuk terbiasa melakukan musyawarah mufakat dalam setiap pengambilan keputusan.

Seperti halnya pemaparan dari Dewitt \& Slade (2014: 14) menjelaskan bahwa iklim akademik yang positif merupakan lingkungan di mana semua orang terlibat dan dihormati di mana mahasiswa, Ketua Program Studi, dan dosen bekerja bersama untuk mengembangkan hidup, dan berkontribusi bersama dalam membangun Program Studi. Iklim akademik yang positif akan mendorong semangat belajar, kohesi kelompok, rasa hormat, dan saling percaya yang telah terbukti bisa secara langsung meningkatkan kualitas lingkungan pembelajaran. Iklim akademik positif menunjukkan hubungan langsung dengan prestasi akademik, yang saat ini menjadi faktor pendorong keberhaSilan belajar mahasiswa. Empat elemen penting pembentuk iklim akademik positif di antaranya; keterlibatan siswa, pemberdayaan, budaya akademik, otonomi,inklusivitas, ekuitas, dan lingkungan.

\section{METODE}

Penelitian ini menggunakan pendekatan kualitatif, dengan jenis studi kasus. Dipilihnya jenis penelitian studi kasus dalam penelitian ini karena musyawarah mufakat yang dalam adat istiadat Lampung disebut bubalah hanya ada dan diterapkan di Universitas Negeri Lampung. Oleh 
kerena itu dengan melihat karakter dari penelitian studi kasus maka jenis penelitian studi kasus sangat cocok diterapkan untuk memperoleh data dalam penelitian ini. Penentuan subjek penelitian dilakukan dengan teknik purposif yang terdiri dari: Ketua Program Studi PPkn FKIP Universitas Lampung, Dosen Program Studi PPkn FKIP Universitas Lampung, dan Mahasiswa Program Studi PPkn FKIP Universitas Lampung. Pengumpulan data dalam penelitian ini dilakukan dengan teknik wawancara mendalam, observasi partisipan, dan analisis dokumen. Uji keabsahan data dilakukan dengan menggunakan trianggulasi sumber dan trianggulasi metode. Analisis data dalam penelitian ini menggunakan teknik analisis kualitatif model Miles dan Huberman dengan langkahlangkah: (1) reduksi data, (2) penyajian data, dan (3) penarikan kesimpulan.

\section{HASIL DAN PEMBAHASAN}

\section{Pelaksanaan Budaya Musyawarah Mufakat (Bubalah) di Program Studi PPKn FKIP Unila}

Bentuk lain dari usaha yang lakukan oleh Program Studi PPkn FKIPUniversitas Lampung untuk menciptakan iklim akademik yang positif, ialah dengan menerapkan budaya musyawarah mufakat (Bubalah). Fattah Bahiki \& Rahmatan (1993: 2) Bubalah itu artinya musyawarah. Bubalah biasa juga disebut Bukhasan Buhimpun atau biasanya lebih dikenal dengan Rasan Buhimpun. Rasan Buhimpun ini sebagai perhimpunannya masyarakat Lampung dalam lingkup adat Lampung. Rasan Buhimpun secara umum adalah berkumpul bersama, berbicara dalam tata cara perijinan yang bersusun berdasarkan maksud untuk menyimpulkan pendapat perbincangan atau ingin bermusyawarah.

Sedangkan Budaya musyawarah mufakat (Bubalah) yang diterapkan Program Studi PPkn FKIP Universitas Lampung merupakan salah satu jalan yang ditempuh untuk membiasakan mahasiswa bertindak adil dan bijaksana dalam setiap penggambilan keputusan. Tujuan Program Studi PPkn FKIP Universitas Lampung mengadopsi tradisi (Bubalah) adalah membiasakan kepada mahasiswa untuk membudayakan musyawarah mufakat dalam setiap penggambilan keputusan, sebagai sarana pengimplementasian salah satu nilai Pancasila, sebagai wadah untuk mengasah sikap demokratis mahasiswa, dan untuk menciptakan iklim yang kondusif dan damai.

Pelaksanaan budaya musyawarah mufakat (Bubalah) yang diselenggarakan di Program Studi PPkn FKIP Universitas Lampung sedikit berbeda dengan pelaksanaan tradisi (Bubalah) yang dilaksanakan di masyarakat, pada umumnya tradisi (Bubalah) yang dilaksanakan di masyarakatakan dilaksanakan pada malam hari, sedangkan di Program Studi PPkn FKIP Universitas Lampung dilaksanakan pada pagi hari dan di hari libur seperti hari sabtu atau minggu. Menurut Fattah Bahiki \& Rahmatan (1993: 5) dalam pelaksanaan perhimpunan (Bubalah) terdapat beberapa aturan yang perlu diperhatikan seperti halnya waktu. Perhimpunan ini sebaiknya di waktu malam, karena tidak bisa selesai cepat. Oleh karena itu, tujuannya dilakukan dimalam hari agar tidak mengganggu pekerjaan lain.

Kelemahan dari sistem musyawarah mufakat yakni dalam proses pengambilan keputusan akan memakan waktu yang cukup panjang, alot dan bahkan akan menimbulkan perseteruan antara pihak minoritas dan mayoritas. Apa bila pihak minoritas tetap bersikukuh untuk tidak setuju akan mengakibatkan keputusan tidak menemui kata mufakat. Sehingga pihak minoritas dapat memaksakan untuk tidak tercapainya keputusan. Kekuasaan minoritas ini dapat menimbulkan "diktatorial minoritas" yang artinya kekuasaan dari kelompok kecil yang menentukan segala sesuatunya. Sebaliknya kelebihan dari musyawarah untuk mufakat adalah semua pihak akan merasa dilibatkan, diikutsertakan, dihargai, dan dihormati aspirasinya, sehingga hasil yang akan dicapai dapat dinikmati oleh seluruh anggota berkepentingan winwin solution (Idris, 2013: 12).

Berkaitan dengan kepentingan bersama, musyawarah mufakat merupakan salah satu warisan budaya bangsa Indonesia, dan juga merupakan salah satu nilai dasar yang tertera pada Sila ke empat Pancasila, yang diseluruh daerah tentunya memiliki budaya musyawarah mufakat dengan nama dan pelaksanaan yang berbedabeda. Budaya musyawarah mufakat tentunya harus terus dijaga keutuhannya, dilestarikan pelaksanaannya, dan dilaksanakan kegiataanya baik itu di lingkungan sosial, keluarga, maupun lingkungan pendidikan. Yang membedakan tradisi (Bubalah) dengan budaya musyawarah mufakat lainnya adalah makna tradisi (Bubalah) itu sendiri yang berarti berkumpul bersama/ duduk bersama untuk menyambung tali kekeluargaan, pelaksanaannya yang mana tradisi (Bubalah) dilaksanakan pada malam hari, dan penentuan keputusan dari (Bubalah) yang murni berdasarkan hasil kesepakatan bersama.

Program Studi PPkn FKIP Universitas Lampung mengadopsi tradisi (Bubalah) menjadi budaya akademik di Program Studi PPkn FKIP Universitas Lampung. Pengadopsian (Bubalah) tersebut dilakukan untuk melestarikan salah satu tradisi adat Lampung yang saat ini mulai tergerus oleh arus globalisasi, ditambah dengan jumlah transmigrasi dari berbagai daerah yang mengakibatkan melunturnya tradisi adat Lampung. Tujuan Program Studi PPkn FKIP Universitas Lampung mengadopsi tradisi (Bubalah) adalah membiasakan kepada mahasiswa untuk membudayakan musyawarah mufakat dalam setiap pengambilan keputusan, sebagai sarana pengimplementasian salah satu nilai Pancasila, sebagai wadah untuk mengasah sikap demokratis mahasiswa, dan untuk menciptakan iklim yang kondusif dan damai. Bentuk lain (Bubalah) yang diterapkan oleh Program Studi PPkn FKIP Universitas Lampung ialah MUBES (Musyawarah Besar) yang dinaungi oleh FORDIKA (Forum Pendidikan Kewarganegaraan). 
Kesadaran civitas akademika terkait pertisipasi dalam mengikuti kegiatan (Bubalah) dapat dikatakan cukup baik, hal tersebut dikarenakan pembudayaan yang diterapkan dari awal sampai saat ini terus berjalan dengan baik. Meskipun demikan, kegiatan (Bubalah) sering kali menemui hambatan seperti halnya faktor kesibukan karena waktu pelaksanaan yang di agendakan pada hari sabtu dan minggu, tidak jarang dijumpai peserta yang hadir pada kegiatan (Bubalah) cenderung minim dan hanya ituitu saja, dan terkadang ditahap acara inti justru banyak peserta yang pulang dan tidak kembali untuk mengikuti kegiatan selanjutnya, hal-hal semacam ini yang terkadang memicu terjangkitnya kevakuman pada kegiatan Bubalah itu sendiri.

Beberapa bentuk budaya musyawarah mufakat yang dilaksanakan di Program Studi PPkn FKIP Universitas Lampung ialah, kegiatan musyawarah mufakat KKL yang dilakukan dengan cara memberikan kesempatan pada mahasiswa untuk menentukan tempat, setelah itu dosen Program Studi PPkn FKIP Universitas Lampung mengelompokkan mahasiswa yang memiliki keinginan yang sama dalam satu kelompok, lalu dosen memberikan arahan kepada mahasiswa untuk membuat proposal sesuai dengan tujuan dari kelompok masing-masing, selanjutnya dosen memaparkan beberapa kompetensi yang harus dicapai dalam pembuatan proposal KKL tersebut diantara: tingkat kemenarikan dari tema yang akan di angkat, konten/ isi proposal, permasalahan yang akan diangkat, tulisan/tata bahasa, dan kandungan nilai-nilai ke PPKn-annya, setelah itu beberapa dosen akan memberikan penilaian terhadap proposal pengajuan lokasi KKL sekaligus menetapkan proposal mana yang layak untuk dijadikan lokasi KKL tersebut.

Musyawarah mufakat merupakan nilai yang dihasilkan dariakar budaya bangsa Indonesia. Musyawarah mufakat secara tegas dinyatakan dalam Sila keempat dasar negara kita, yaitu Pancasila. Sila keempat Pancasila menegaskan bahwa prinsip kerakyatan Indonesia harus dijalankan dengan cara permusyawaratan yang bijaksana. Desi \& Cahyo (2014: 2) berpendapat bahwa kebebasan dalam berpendapat merupakan salah satu aspek dalam musyawarah untuk mufakat, musyawarah mufakat dilakukan dengan cara pengambilan keputusan melalui kesepakatan bersama dalam artian suara mayoritas memiliki wewenang atas Hak bersuara dan penghargaan atas Hak individu sudah dapat dipenuhi dalam proses pengambilan keputusan. Karenanya pemilihan dengan suara terbanyak dapat dikatakan sebagai proses yang demokratis, tanpa melanggar kesepakatan adat dan juga aturan-aturan dalam kerangka Pancasila dan UUD 1945.

Pancasila dan UUD 1945 merupakan pedoman sekaligus landasan dasar pelaksanaan budaya musyawarah mufakat (Bubalah) yang diterapkan Program Studi PPkn FKIP Universitas Lampung. Sebagai salah satu Program Studi yang mengkaji nilai moral Pancasila, sudah menjadi kewajiban bagi seluruh civitas akademika Program Studi
PPkn FKIP Universitas Lampung, mengamalkannya nilai-nilai yang terkandung dalam Pancasila serta diterapkan dalam kehidupan nyata. Melaksanakan budaya musyawarah mufakat (Bubalah) berarti sama halnya dengan menjalankan amanat dari Pancasila. Program Studi PPkn FKIP Universitas Lampung mencoba membangkitkan kembali semangat kebangsaan generasi muda bangsa Indonesia, melalui pelestarian warisan budaya bangsa musyawarah mufakat (Bubalah).

Berkaitan dengan pelaksanaan budaya musyawarah mufakat (Bubalah) yang diterapkan oleh Program Studi PPkn FKIP Universitas Lampung, Islamey (2011: 4), memaparkan bahwa ciri-ciri musyawarah dan mufakat sebagai berikut:

1. Masalah yang dibicarakan merupakan kepentingan bersama.

2. Pembicaraan harus dapat diterima dengan akal sehat dan sesuai hati nurani yang luhur.

3. Proses musyawarah selalu mempertimbangkan moral.

4. Usul atau pendapat mudah dipahami dan masuk akal.

5. Hasil keputusan tidak memberatkan warga atau rakyat.

6. Musyawarah untuk mufakat mengedepankan kekeluargaan, kebersamaan, kesabaran, jujur, saling memberi atau menerima masukan.

Sehubungan dengan penjelasan di atas, budaya musyawarah mufakat (Bubalah) yang di terapkan oleh Program Studi PPkn FKIP Universitas Lampung, juga senantiasa menjunjung kesepakatan bersama dan mengedepankan asas kekeluargaan. Menanggapi hal itu, Ketua Program Studi PPkn FKIP Universitas Lampung menjelaskan tentang langkah yang akan ditempuhnya, ketika musyawarah tidak sampai pada titik mufakat ialah dengan melakukan pendekatan yang lebih intens lagi untuk duduk bersama dan mencari penyelesaian bersama. Karena saya yakin sekeras-kerasnya batu karang di lautan akan retak bila ditetesin air terus menerus begitupun dengan manusia.Dan memilih jalan voting itu bukan demokrasi, voting itu hanyalah jalan pintas untuk mengakhiri suatu permasalahan yang tidak ada titik temu. Dan menurut saya voting itu tidak sesuai dengan paradigma demokrasi.

Melaksanakan budaya musyawarah mufakat (Bubalah) merupakan sebuah keteladanan yang memiliki beragam manfaat, salah satu manfaat yang diperoleh mahasiswa Program Studi PPkn FKIP Universitas Lampung, dengan menerapkan budaya musyawarah mufakat diantaranya: sebagai sarana melatih kesabaran, wadah untuk membentuk sikap demokratis, memperdalam wawasan, menambah teman, dan mengisi waktu luang. Seperti halnya pemaparan dari Widihastuti dan Rahyuningsih (2008: 60), mendekripsikan beberapa manfaat musyawarah antara lain:

1. Musyawarah bisa menyelesaikan masalah lebih mudah.

2. Musyawarah dapat memperkokoh kerukunan.

3. Musyawarah dapat mempererat kerja sama. 
4. Musyawarah mengajari kita menghormati orang lain.

Ciri khas dari Program Studi PPkn FKIP Universitas Lampung yang sangat menonjol terletak pada iklim dan budaya akademiknya, di mana terdapat nuansa kekeluargaan yang sangat erat di antara civitas akademika tanpa menghilangkan etika dan sopan santun di dalamnya, ketika di luar kelas mereka berbaur layaknya seorang teman yang terlihat begitu akrab dan terbuka namun, berbeda ketika mereka di tempatkan dalam situasi perkuliahan di mana status dosen dan mahasiswa terlihat sangat jelas. Selain nuansa kekeluargaan Program Studi PPkn FKIP Universitas Lampung sangat menjunjung tinggi asas demokrasi dengan mengangkat musyawarah mufakat (Bubalah) sebagai budaya akademik yang senantiasa di lestarikan guna mempertahankan tradisi adat Lampung yang sekaligus merupakan pengimplementasian dari Sila ke empat Pancasila.

Sesuai dengan pernyataan di atas Menurut Elly M. Setiadi (2005: 155), Sila Kerakyatan yang dipimpin oleh hikmahkebijaksanaandalampermusyawaratan/perwakilan secara eksplisit menyebut istilah kerakyatan, dan bukan demokrasi. Yang dimaksud "hikmah kebijaksanaan dalam permusyawaratan" adalah musyawarah untuk mufakat. Kerakyatan tidak berarti sama dengan demokrasi liberal yang berprinsip pada musyawarah untuk mufakat tanpa diperkenankan melakukan pemungutan suara, sehingga dapat menimbulkan hak veto atau diktator minoritas. Musyawarah untuk mufakat adalah ciri khusus Indonesia. Nilai dalam pengembangan Pancasila khususnya Sila keempat yaitu:

1. Mengakui bahwa manusia Indonesia memiliki kedudukan dan hak yang sama.

2. Melaksanakan keputusan bersama dengan penuh tanggung jawab dan iktikat baik.

3. Mengambil keputusan yang harus sesuai dengan nilai kebenaran dan keadilan.

\section{Iklim Akademik Di Program Studi PPkn FKIP Universitas Lampung}

Iklim akademik merupakan aspek penunjang dalam pembentukan sikap demokratis mahasiswa Program Studi PPkn FKIP Universitas Lampung. Diketahui bahwa iklim akademik yang diterapkan oleh Program Studi PPkn FKIP Universitas Lampung, senantiasa mengedepankan asas kekeluargaan dalam membangun kehidupan akademik yang harmonis. Tingkat keharmonisan yang ditunjukan oleh Program Studi PPkn FKIP Universitas Lampung terlihat pada jalinan hubungan yang dibangun oleh setiap civitas akademika yang ada di dalamnya melalui beragam kegiatan yang positif. Beragam kegiatan dilaksanakan untuk memupuk tali Silaturahmi diantara civitas akademika Program Studi PPkn FKIP Universitas Lampung, seperti halnya kegiatan Mubes (Musyawarah Besar), merupakan salah satu kegiatan yang diangkat untuk membangun integritas Program Studi PPkn FKIP Universitas Lampung.

Sesuai dengan pernyataan tersebut Kurniawan (2013: 16) memaparkan bahwa, iklim akademik yang ideal dapat digambarkan dengan berbagai kegiatan yang dilakukan di lingkungan kampus yang ditandai oleh munculnya interaksi yang harmonis, dan hubungan timbal balik yang baik antara dosen dan mahasiswa. Misalnya: diskusi, penelitian, penulisan karya ilmiah, debat, mimbar bebas, kajian, dan diberbagai forum kegiatan lainnya. Iklim akademik yang dibentuk oleh Ketua Program Studi PPkn FKIP Universitas Lampung terkesan positif, kesan positif yang ditimbulkan seperti budaya musyawarah mufakat (Bubalah) yang kian kental, asas kekeluargaan yang terus dijaga, peningkatan kualitas pendidikan, dan layanan akademik.

Menanggapi pemaparan tersebut Jain, et al (2011: 296) mengatakan bahwa dalam membentuk kualitas pelayanan pada perguruan tinggi dibutuhkan performans intelektual yang terdiri dari dua dimensi pokok diantaranya: kualitas program dan kualitas hidup. Kualitas program meliputi: kurikulum, interaksi, kualitas masukan, dan fasilitas akademik. Sedangkan kualitas hidup meliputi: proses non akademik, fasilitas pendukung, kualitas kampus dan interaksi. Pada dasarnya dalam menciptakan kualitas pembelajaran dan interaksi yang baik, di dalam lingkungan kampus dibutuhkan lembaga pendidikan yang layak dan relevan guna mencetak mahasiswa yang berkualitas.

Salah satu upaya yang dilakukan oleh Program Studi PPkn FKIP Universitas Lampung, untuk menghasilkan mahasiswa yang berkualitas adalah dengan memberikan pendidikan yang terjamin, pelayanan yang berkualitas, dan fasilitas yang memadai. Sebagaimana semestinya tugas perguruan tinggi yang dituntut untuk mencerdaskan kehidupan bangsa, begitu juga dengan Program Studi PPKn Universitas Lampung, yang terus berupaya untuk memberikan pendidikan secara maksimal guna menghasilkan lulusan yang professional. Menanggapi penjelasan di atas Suwanto (2009: 79) menegaskan bahwa profesionalitas dosen terbentuk dan dipengaruhi oleh efektifitas kepemimpinan Ketua Program Studi dan iklim akademik yang positif. Iklim akademik memberikan kontribusi yang positif, di mana peran dari kondisi lingkungan akademik memberikan dorongan terhadap kemampuan profesionalitas dosen dalam mengajar. Karena pada dasarnya terciptanya lingkungan yang aman, damai, tentram, menyenangkan, dan kondusifmemberikan motivasi dan semangat tersendiri untuk menebarkan ilmu pengetahuan.

Kondisi lingkungan merupakan salah satu unsur pokok dalam mendukung berjalannya proses perkuliahan, kelancaran proses perkuliahan juga di tentukan lewat kondisi lingkungan yang memadai. Universitas Lampung terkenal dengan sebutan green campus karena lingkungannya yang sejuk, rindang, jauh dari 
keramaian, wilayah yang luas, dan bersih. Berdasarkan hasil wawancara, observasi, dan dokumentasi kondisi lingkungan di Program Studi PPkn FKIP Universitas Lampung pada tahun 2017-2018 sudah mengalami peningkatan yang cukup signifikan dibanding dengan tahun-tahun sebelumnya, berbagai perubahan sedikit demi sedikit mulai dirasakan. Seperti halnya perubahan kondisi bangunan program studi PPKn yang awalnya terdiri satu lantai, kini sudah di renovasi menjadi dua lantai, fasilitas ruang tunggu yang semakin nyaman dengan adanya fasilitas kursi yang cukup banyak dan nyaman, kondisi lingkungan yang semakin bersih dan tertata dibandingkan sebelumnya, dan tingkat keamanan yang semakin terjaga dengan diberlakukan kartu parkir untuk meminimalisir pencurian motor, hubungan antar civitas akademika semakin solid dengan tetap menjaga iklim akademik yang harmonis, dan proses perkuliahan yang semakin kondusif dengan memberlakukannya inovasi pembelajaran. Sesuai dengan pemaparan di atas Fisher \& Fraser (1990: 187) juga menyatakan bahwa peningkatan mutu lingkungan kerja di kampus dapat menjadikan kampus lebih efektif dalam memberikan proses pembelajaran yang lebih baik.

Beranjak dari pemaparan tersebut D. Maramba \& S. Museus (2013: 495) menggambarkan tentang iklim kampus secara khusus, melalui dua faktor yang mempengaruhi iklim kampus tersebut yaitu lingkungan akademik itu sendiri dan perilaku siswa. Sebagai langkah awal yang harus dilakukan Program Studi PPkn FKIP Universitas Lampung dalam membentuk iklim akademik yang positif adalah dengan membentuk kondisi lingkungan yang nyaman, tenang, dan menyenangkan. Faktor pendukung terciptanya suasana yang nyaman bagi mahasiswa untuk belajar adalah kondisi ruangan yang didukung dengan lingkungan yang kondusif. Kondisi ruangan yang nyaman akan menumbuhkan motivasi dan semangat belajar mahasiswa semakin tinggi, meskipun pada dasarnya tingkat kenyamanan seseorang itu berbeda-beda.

Perbedaan merupakan bentuk dari kesempurnaan, dengan sikap dan karakter mahasiswa Program Studi PPkn FKIP Universitas Lampung yang beranekaragam, perbedaan tidak lantas membuat jarak di antara mereka semakin menjauh, perbedaan justru dimaknai sebagai pelengkap dari celah-celah kekurangan yang ada. Perbedaan adalah situasi yang wajar di mana mahasiswa Program Studi PPkn FKIP Universitas Lampung terdiri dari beragam daerah, suku, dan agama, dengan pola pikir yang berbeda-beda. Salah satu bentuk usaha yang dilakukan oleh Program Studi PPkn FKIP Universitas Lampung, untuk menjembatani perbedaan tersebut ialah dengan menyatukan mereka dalam bingkai kekeluargaan. Sejalan dengan penjelasan tersebut A. Rockenbach\&M. Mayhew (2013: 4) menjelaskan bahwa, iklim akademik di perguruan tinggi memiliki peranan agama atau kepercayaan yang sangat digencarkan, karena suatu agama di pandang mampu melahirkan nilai-nilai yang membangun karakter siswa, dan mengajarkan arti toleransi dalam keberagaman dan menghargai perbedaan. Melalui iklim akademik di Program Studi PPkn FKIP Universitas Lampung, Ketua Program Studi berharap mahasiswa mampu untuk bersosialisasi dan beradaptasi dengan kondisi lingkungan, budaya, suasana, dan warga yang ada di dalamnya. Meskipun benar, fenonema bergeng juga tidak luput dari kebiasaan mahasiswa Program Studi PPkn FKIP Universitas Lampung, fenomena tersebut lahir dari kondisi sosial dan ekonomi yang mendasari mahasiswa Program Studi PPkn FKIP Universitas Lampung untuk menemukan teman yang sesuai dengan apa yang ia inginkan.

Berdasarkan pemamaran tersebut Park. J.J, et al (2013: 466-496) menegaskan bahwa keberagaman dalam lingkungan akademik tidak selalu menyoal etnik dan ras, akan tetapi keberagaman sosial, ekonomi memberikan warna tersendiri terhadap pembentukan iklim kampus. Selain perbedaan, iklim kampus terbentuk melalui hubungan civitas akademik yang ada di sebuah perguruan Tinggi. Hubungan akademika memiliki peranan yang besar dalam menunjang terbentuknya iklim akademik di sebuah Perguruan Tinggi. Hubungan civitas akademika di Program Studi PPkn FKIP Universitas Lampung terbilang sangat harmonis, karena keharmonisan itulah yang ditanamkan ketua program studi kepada kami semua. Dan untuk menjaganya, dibutuhkan tali kekeluargaan yang erat, saling menghormati, dan menghargai, serta membudayakan musyawarah mufakat dalam setiap pengambilan keputusan itu yang saya rasakan dari hubungan yang selama ini terjalin di Program Studi PPkn FKIP Universitas Lampung.

Salah satu metode yang digunakan oleh ketua Program Studi PPkn FKIP Universitas Lampung dalam rangka menciptakan suasana yang harmonis dan hubungan yang baik yaitu dengan cara meluangkan waktu sejenak untuk dapat berkumpul dengan dosen dan mahasiswa, dan menjadi sesosok yang mampu mengayomi, membimbing, dan menjadi suri teladan yang baik untuk civitas akademika di Program Studi PPkn FKIP Universitas Lampung. Beberapa bentuk sikap yang sering dicontohkan ketua program studi yakni: tidak sungkan meminta maaf kepada mahasiswa, dosen ataupun staff ketika dirinya salah, tidak ragu-ragu untuk mengucapkan terimakasih ketika dirinya mendapati bantuan dari mahasiswa, dosen, ataupun staff, tidak sungkan untuk menyapa dosen, mahasiswa, dan staff terlebih dahulu, tidak malu untuk bertanya atau meminta bantuan kepada dosen, mahasiswa, dan staff ketika dirinya tidak tahu, dan tidak canggung untuk berbaur untuk mengobrol maupun berdiskusi dengan mahasiswa, dosen, dan staff. Menurut ketua Program Studi PPkn FKIP Universitas Lampung seluruh warga Program Studi PPkn FKIP Universitas Lampung memiliki hak dan kewajiban yang sama, diperlakukan dengan sama tanpa dibeda-bedakan semuanya rata, sejajar, dan tanpa adanya diskriminasi.

Hubungan yang baik antara civitas akademika terlihat dari etika dan tata krama mahasiswa ketika 
hendak bertemu atau menemui dosen, serta sopan santun mahasiswa PPKn FKIP Universitas Lampung saat berbicara maupun bersikap dengan dosen. Sedangkan keharmonisan civitas akademika Program Studi PPkn FKIP Universitas Lampung tergambar melalui keterbukaan mahasiswa kepada dosen terkait persoalan perkuliahan maupun persoalan lainnya, selain terbuka mahasiswa dan dosen Program Studi PPkn FKIP Universitas Lampung terlihat bersahabat ketika berada di luar proses perkuliahan.

\section{Peranan Budaya Musyawarah Mufakat (Bubalah) Dalam Membentuk Iklim Akademik Yang Positif}

Konsep dasar iklim dan budaya akademik mengacu pada karakteritis dari sebuah Universitas, yang nantinya akan digunakan sebagai panduan penyelenggaraan proses perkuliahan yang ada. Iklim dan budaya akademik berkembang melalui tingkat-tingkat revolusi tertentu, secara praktis iklim dan budaya akademik merupakan proses pembentukan identitas dari sebuah Universitas. Iklim dan budaya akademik merupakan cerminan yang akan menggambarkan kondisi lingkungan di sebuah Universitas, hubungan, budaya, dan sikap dari warganya itu sendiri. Sejalan dengan pemamaparan tersebut Tilaar (1999: 180) menjelaskan bahwa pengembangan sikap demokratis bukan hanya membentuk jati diri individu yang beraneka ragam, akan tetapi didukung dengan sistem yang mengembangkan sikap demokratis tersebut.

Berdasarkan hasil penelitian menunjukkan bahwa peranan budaya musyawarah mufakat (Bubalah) dalam membentuk iklim akademik yang positif terlihat dari aktifitas kegiatan mahasiswa yang berjalan kondusif, kegiatan perkuliahan yang semakin inovatif, hubungan civitas akademika yang harmonis, dan terbentuknya sikap mahasiswa yang demokratis. Dibalik semua itu budaya musyawarah mufakat (Bubalah) berperan sebagai pedoman dalam pembentukan iklim akademik di Program Studi PPkn FKIP Universitas Lampung. Budaya musyawarah mufakat (Bubalah) memberikan rangsangan terhadap lingkungan disekitarnya untuk terbiasa melakukan musyawarah mufakat dalam setiap pengambilan keputusan.Seperti halnya pemaparan dari Dewitt \& Slade (2014: 14) menjelaskan bahwa iklim akademik yang positif merupakan lingkungan di mana semua orang terlibat dan dihormati di mana mahasiswa, Ketua Program Studi, dan dosen bekerja bersama untuk mengembangkan hidup, dan berkontribusi bersama dalam membangun Program Studi.

\section{SIMPULAN}

Berdasarkan hasil pembahasan mengenai peranan budaya musyawarah mufakat (Bubalah) terhadap pembentukan iklim akademik yang positif, terbukti dari budaya musyawarah mufakat (Bubalah) dapat mempengaruhi kondisi lingkungan akademik di Program
Studi PPkn FKIP Universitas Lampung dan sikap dari warga yang ada di dalamnya. budaya musyawarah mufakat (Bubalah) membiasakan mahasiswa untuk terus bersikap demokratis, sehingga mau tidak mau, atau suka tidak suka, sikap mahasiswa dan iklim akademik secara tidak langsung akan terbentuk sesuai dengan budaya yang ada di sekitarnya.

\section{DAFTAR PUSTAKA}

Rockenbach, A. \& Mayhew, M. (2013). How the Collegiate Religiousand Spiritual Climate Shapes Students Ecumenical Orientation. Research in Higher Education, 54 (4), 461-479.

Maramba, D. \& Museus, S. 2013. Examining The Effects Of Campus Climate, Ethnic Group Cohesion, and Cross Cultural Interaction OnFilipino American Students Sense Of Belonging In College. Journal of College StudentRetention: Research, Theory \& Practice, 14 (4), 495-522.

Desi, P. \& Cahyo, S. (2014). Musyawarah Mufakat atau Pemilihan Lewat Suara Mayoritas? Diskursus Pola Demokrasi Di Indonesia. Jurnal Ilmiah Mimbar Demokrasi. 13, (2), 1-13.

Dewitt, P. \& Slade, S. (2014). School Climate Change. USA: ASCDAlexandria.

Elly, M.S. (2005). Panduan Pendidikan Pancasila Untuk Perguruan Tinggi. Jakarta: Gramedia Pustaka Utama.

Fattah, B. \& Rahmatan. (1993). Tangguh Rasan Buhimpun. Bandar Lampung: Gunung Pesagi.

Fisher, D.L., \& Fraser, B.J. (1990). School climate: Assessing and improving school environments (Set: Research Information for Teachers No. 2, Item 4). Melbourne, Australia: Australian Council for Educational Research.

Hindaryatiningsih, N. (2016). Model Proses Pewarisan Nilai-nilai Budaya Lokal Dalam Tradisi Masyarakat Buton. Sosiohumaniora, 18, (2), 108-115.

https://nasional.kompas.com/read/2011/08/18/13170468/ Budaya.Musyawarah.Mufakat.Makin.Luntur. Diakses pada tanggal 18 Februari 2018 pada jam 13:54 wib

Idris, T. (2013). Bentuk Putusan Penyelesaian Sengketa Melalui Mediasi. Lex et Societatis, 1, (1). 19-30.

Islamey, A. (2011). Penerapan Demokrasi Pancasila. Jurnal ilmiah-PKn. STMIK AMIKOM Yogyakarta. 1, (4), 4-9

Jain, R., Sinha, G. \& Sahney, S. (2011). Conceptualizing Service Quality in Higher Education. Asian Journal on Quality, 12 (3), 296-314. 
Kausar. (2013). Budaya Organisasi Pemerintahan Daerah Kabupaten Tulang Bawang Lampung. Sosiohumaniora. 15, (1), 26-34.

Kurniawan, A.W. 2013 Manajemen Konflik dalam Mengembangkan Atmosfer Akademik. Jurnal Strategi dan Bisnis, 1, (1), 16-30.

Park, JJ., Denson, N. \& Bowman, N.A. (2013). Does Socioeconomic Diversity Make a Difference, Examining the Effects of Racial and Socioeconomic Diversity on the CampusClimate for Diversity. American Educational Research Journal, 50, (3), 466-496.
Suwanto, (2009). Hubungan Keefektifan Kepemimpinan Kepala Sekolah danIklim Sekolah Terhadap Profesionalitas Guru Pada Sekolah Dasar Negeri diKecamatan Ngadirojo Kabupaten Wonogiri. Tesis Teknologi Pendidikan.Surakarta.

Tilaar, H.A.R. (1999). Pendidikan Kebudayaan, dan Masyarakat Madani Indonesia. Bandung:PT Remaja Rosdakarya.

Widihastuti, S. \& Rahyuningsih, F. (2008). Pendidikan Pancasila: SD/MI kelas II. Jakarta: Pusat Perbukuan Departemen Pendidikan Nasional. 